\title{
Effect of Fortified Pan Bread with Melissa Officinalis L. on Induced Oxidative Stress in Rats.
}

\author{
Asmaa M.I.El Gamel \\ ${ }^{1}$ Fellow (Lecturer) of Nutrition and Food Science, Ahmed Maher Teaching \\ Hospital, Egypt.
}

\begin{abstract}
Melissa officinalis L(MO) is also known as bee balm, lemon balm, honey balm, and is a perennial herb. It is a member of the Lamiaceae family Which is often referred to as (the mint family). The influence of diet containing fortified bread with(5, $7.5,10 \%)$ Meliss powder(MP) on rats suffering from oxidative stress has been studied. Fortified bread with $(5,7.5,10 \%)$ MP were prepared and were subjected to sensory evaluation. The best level of fortified bread after sensory evaluation was $5 \%$ but the best level of fortified bread after the biological study was $10 \%$. The chemical composition of bread was estimated at $5 \%$ due to its acceptance in sensory evaluation. Twenty five male albino rats $(170-190 \mathrm{~g})$ were randomly distributed into 5 equal groups, of 5 rats each. Group 1 was fed on the basal diet containing unfortified pan bread and kept as a negative control group. The other 4 groups $(\mathrm{n}=20$ rats), were injected with a single intraperitoneal dose of $125 \mathrm{mg} / \mathrm{kgbw}$ of potassium bromate $\left(\mathrm{KBrO}_{3}\right)$ for oxidative stress induction group 2 was fed on the basal diet, which includes unfortified pan bread as positive control rats, groups 3,4 and 5 were fed on diet containing fortified pan bread with $(5,7.5 \& 10 \%) \mathrm{MP}$ respectively. The obtained results revealed that the injected groups with levels $10 \%$ of diet containing fortified bread with MP had significant decrease in serum levels of lipid profile (total cholesterol, triglycerides, LDL , VLDL), kidney,liver function and serum malondialdehyde (MDA) and significant increased in serum levels of HDL, total antioxidant capacity (TAC), glutathione (GSH), levels of glutathione peroxidase (GPX), superoxide dismutase (SOD) and catalase (CAT) enzymes. Moreover, there was a significant reduced in MDA and increase in GSH levels and the activity of antioxidant enzymes(GPX, SOD and CAT)in liver tissues as well as partially improvements in liver structures compared to positive intoxicated "control group", but non significant increase in $(\mathrm{BWG} \%)$, FI and FER which nearly returned toward the negative control group. The best improvements among all the biochemical parameters and histological structures of liver which were tended toward normal results were observed in group treated with bread fortified 10\%MP.In conclusion, the present findings suggested that regular intake from $10 \%$ fortified bread with MP may be useful
\end{abstract}


in improving liver and kidney functions and may protect against potassium bromate $\left(\mathrm{KBrO}_{3}\right)$ which induced oxidative stress in rats.

Keywords: Antioxidant enzymes ,liver functions, kidney functions, Lipid profile, Melissa officinalis $L$, oxidative stress, rats.

\section{Introduction}

Oxidative stress is defined as increased production of reactive oxygen species (ROS) that exceeds existing antioxidant defence mechanisms. (Hyunjin Noh and Hunjoo Ha, 2011). It plays a major role in the aetiology and pathogenesis of many chronic diseases, (Krajcovicova-Kudlackova et al.,2012). The hallmarks of many chronic diseases and cell death are oxidative stress associated with oxygen-free radicals and the subsequent tissue destruction (Mates et al.,2002). The healing ability of medicinal plants as natural antioxidants to mitigate tissue damage inflicted by free radicals and to preserve health and defence against such age-related degenerative diseases such as cancer and coronary heart disease (Pourmorad et al., 2006).

Melissa officinalis $L(M O)$ is also known as bee balm, lemon balm, honey balm, and is a perennial herb. It is a member of the Lamiaceae family Jastrzebska-Stojko et al.,(2013). Melissa officinalis (M. officinalis) is a medicinal herb native to the Eastern Mediterranean and Western Asia (Emamghorishi and Talebianpour , 2009). (MO) can be considered an effective agent rats for the prevention of different neurological disorders associated with oxidative stress. (Sepide Miraj et al.,2017).( MO) contains a rich amount of natural antioxidants and is beneficial in many diseases of oxidation. (Hasani-Ranjbar et al., 2009). A recent research found that Lemon balm protects against oxidative stress in subjects exposed to long-term low-dose ionizing radiation (Zeraatpishe et al., 2011). The antioxidants are known to play an important role in protecting against oxidant damage-induced disorders. Production of reactive oxygen species ( ROS) can surpass Cellular antioxidant defenses called oxiditave stress (Capecka et al.,2005).

The antioxidants in plants are widely known for shielding humans from free radicals and avoiding other diseases. The leaves of Melissa officinalis contains polyphenolic compounds, such as rosmaric acid, trimeric compounds and other flavonoids, which can scavenge free radicals and have antioxidant effects. (Zeraatpishe et al.,2011). Lemon balm (Melissa officinalis) is considered herbal medicine to treat headaches, gastrointestilal disorders, nervousness and rheumatisms and the essential oil of $(M O)$ which is rich in aldehydes and terpenic alcohols (Robeiro et al.,2004) is reported to have anti- 
microbial properties as well as a strong protective ability against lipid peroxidation (Mimica-Dukic et al., 2004).

Melissa officinalis that plant rich in flavonoids and phenols in general, which are the highly effective free radical scavenging and antioxidants. Polyphenol and flavonoids are used to prevent and cure of various diseases (Deepa et al.,2009). Flavonoids, a group of pholyphenolic compounds with known properties, such as free radical Melissa activity, inhibition of hydrolytic and oxidative enzyme and anti inflammatory action (Omale and Okafor, 2008). Dry herbs were abundant in tannins and rutin. Tannins exhibit many biologically important functions (Atanassova and Christova-Bagdassarian, 2009). In human diets tannins are the most available antioxidants (Has et al.,2007). Lemon balm infusions boost oxidative stress in workers as used as a dietary supplement (Davood Fazli et al.,2012). A collection of flavonoids from medicinal plants were investigated for their function as microsomal lipid peroxidation inhibitors and in vitro oxygen-free radicals scavengers as well as a xenobiotic toxicity model in the mouse (Sanz et al.,1994). Melissa officinalis is regarded as a useful herbal plant for the prevention of various neurological diseases such as Alzheimer's (Mohammad et al.,2012).

Melissa powder contain moisture, protein, fat, ash, fiber and carbohydrates as follow 17.73 , 7.60, 1.30, 0.71, 1.41 and 71.35\% respectively(Hayam,2020).

Therefore the present study was designed to study of the effect of fortified bread with Melissa officinalis L. against (KBro3)induced oxidative stress in" rats"as animal model.

\section{Materials}

\section{Materials and Methods}

- Fresh plant of Melissa officinalis L were obtained from National Research

Center (NRC) in Dokki,Cairo,Egypt.

- Casein, vitamins, minerals, cellulose, choline chloride and potassium

bromate(KbrO3) were purchased from El-Gomhoreya Company, Cairo, Egypt.

- Oil and starch,sugar,salt and wheat flour(72\% extraction)were purchased from local market, Cairo, Egypt.

- Twenty-five male albino rats (Sprague Dawley Strain) were obtained from Food Technology Res. Institute, Giza.

\section{Methods}

\section{Preparation of Melissa officinalis $L$ powder:}

Melissa officinalis $L$, was washed with flowing tap water and dried with solar energy, $\left(10.5\right.$ in hours) temperature $\left(50^{\circ} \mathrm{C}\right)$ relative humidity $21 \%$ Ibrahim,(1999). The whole quantity was transferred to the solar cabinet dryer 
chamber of the solar energy laboratory at the National Research Center for dehydration after which the dried plant was grounded in fine powder.

\section{Preparation of Melissa officinalis $L$ Fortified Pan Bread :}

The standard formula was according to Abdelghafor et al.,(2011) The ingredients Included $1000 \mathrm{~g}$ of wheat flour(wheat flour extracting rate $72 \%$ ), $15 \mathrm{~g}$ instant yeast, $10 \mathrm{~g}$ salt $(\mathrm{NaCl}), 10 \mathrm{~g}$ Improver(goldenpack), $40 \mathrm{~g}$ sugar ( sucrose). Three formulas were prepared with different levels of Melissa officinalis $L$ powder $5 \%, 7.5 \%$ and $10 \%$ on wheat flour replacement basis and pure water added to make the dough. All dry ingredients were weighed and placed in a mixer for $5 \mathrm{sec}$, and then a suspension of the yeast in water was added. The mixture was further run at high speed for $92 \mathrm{sec}$ and water was added to the mixture for creating the dough.The dough was scaled into three portions, rounded into balls by hand in a fermentation bowls and placed in fermentation cabinet at $30^{\circ} \mathrm{C}$ and 85 percent relative humidity for $20 \mathrm{~min}$. The fermented doughs were placed in pans and finally returned into the fermentation cabinet for $50 \mathrm{~min}$. The pans were put in a convection oven at 212 ${ }^{\circ} \mathrm{C}$ for $18 \mathrm{~min}$. sensory assessment of loaves was registered.

Chemical analysis of un-fortified and fortified bread with (5\%) Melissa officinalis $L$ powder:

Chemical analysis of un-fortified and fortified bread with( 5\%) Melissa officinalis $L$ powder including protein, carbohydrate, fat, moisture and ash were determined in Food Technology Res. Institute according to the method described by the(A.O.A.C.,2003).

Determination of total flavonoids for un-fortified and fortified bread with $(5,7.5,10 \%)$ Melissa officinalis $L$ powder:

Total flavonoids were estimated using the method of Ordonez et al.,(2006).

\section{Determination of total phenolics for un-fortified and fortified bread} with $(5,7.5,10 \%)$ Melissa officinalis $L$ powder:

Total phenol contents were determined by the modified Folin- Ciocalteu method of Wolfe et al.,(2003).

Sensory evaluation of un-fortified and fortified bread with $(5 \%, 7.5$ and $10 \%$ ) Melissa officinalis $L$ powder:

Sensory evaluation was performed by invited ten panelists of the staff members from Food Technology Res. Institute , Ministry of Agriculture, Giza. Each panelist was asked to evaluate unfortified and fortified bread samples with 5, 7.5 and $10 \%$ (Melissa powder), according to color, odor, taste, volume, texture tenderness and general acceptability (Abd El-Latif 1990). According to general acceptability the best level of fortified bread was $5 \%$. 


\section{The biological assay:}

Male albino rats Spargue Dawley Strain (25 rats) weighing (170 -190 g) were kept in individual stainless steel cages under hygienic conditions and fed one week on basal diet according to Reeves et al ., (1993) for adaptation at ad libitum in the animal house of Agricultural Res. Center in Ministry of Agriculture, Giza. After this period, the rats were divided into two main groups , the first main group ( $\mathrm{n}=5$ rats) fed on basal diet containing $(300 \mathrm{~g} / \mathrm{kg}$ diet) unfortified bread and kept as a control negative group. The second main groups (20 rats) were injected by a single intraperitoneal dose of potassium bromate at dose of $125 \mathrm{mg} / \mathrm{kg}$ body weight for induction of oxidative stress according to the described methods by Khan and Sultana(2004) the injected groups were divided into 4 subgroups as the following, subgroup 2 fed on basal diet containing $(300 \mathrm{~g} / \mathrm{kg}$ diet) un-fortified bread as positive control group, subgroups 3,4 and 5 were fed on diet containing ( $300 \mathrm{~g} / \mathrm{kg}$ diet) fortified bread with $(5 \%, 7.5 \%$ and $10 \%)$, respectively.

During the experimental period (five weeks), each rat was weighed every week and food consumption was recorded. The body weight gain\%(BWG) and feed efficiency ratio (FER) were determined according to Chapman et al., (1959) using the following formula:

$$
\left(B W W^{G} \%\right)=\frac{\text { Final Welght_Initlal Welght }}{\text { Initlal Welght }} \times_{100}
$$

$$
(\text { FER })=\frac{\text { Dally body Welght galn }(\mathrm{g})}{\text { Feed intake }(\mathrm{g} / \mathrm{d})}
$$

At the end of the experimental period rats were fasted over night before sacrificing blood was collected then centrifuged. Serum was separated and stored at $-20^{\circ} \mathrm{c}$ for biochemical analysis i.e. serum total cholesterol(TC) and triglycerides(TG)were according to Schettler and Nussel, (1975), high density lipoprotein cholesterol (HDL-c) Lope Virella et al., (1977), low density lipoprotein cholesterol (LDL-c ) and very low density lipoprotein cholesterol (VLDL-c)were according to Fried wald et al., (1972), aspartate amino transferase (AST) and alanine amino transferase (ALT) Reitman and Frankel, (1957), serum alkaline phosphates (ALP) Belfield and Goldberg, (1971), serum uric acid Fossati et al., (1980), urea (Marsch et al., 1965), Creatinine Bartels and Bohmer, (1971),serum malondialdehyde (MDA) Draper and 
Hadley (1990),glutathione (GSH) Beutler et al.,(1963).Serum activity of glutathione peroxidase (GPX), superoxide dismutase (SOD) and catalase (CAT) enzymes were assayed according to the method of Hissin and Hiff (1976), Kakkor et al. (1984) and Sinha(1972), respectively. Serum total antioxidant capacity(TAC) Woodford and Whitehead (1998).

Assay levels of (GSH) and activity of antioxidant enzyme in liver tissues:

Oxidant and antioxidant status in liver tissues includes(MDA) Albro et al. (1986). Non-enzyme antioxidant as (GSH) in liver tissues Beutler et al. (1963). Activities of antioxidant enzyme of GPx, SOD and CAT in liver tissues Paglia and Valentaine (1979), Nishikimi et al. (1972) and Aebi (1984),respectively.

\section{Preparation of liver tissue homogenate:}

Part of liver of all animals were cut into small pieces and were determined as described by(Montgomery and Dymock, 1961).

\section{Histopathological Examination}

liver tissue was separated from each rat and examined histopathologicaly Bancroft et al., (2012).

\section{Statistical analysis}

The results were expressed as means \pm SD statistically analyzed using oneway (ANOVA) test, $\mathrm{p}<0.05$ was used to signal significance Steel and Torri, (1980).

\section{Results and Discussion}

Table (1): Chemical analysis of un-fortified and fortified bread with $5 \%$ Melissa powder.

The chemical analysis of un-fortified and fortified pan bread with $5 \%$ Melissa powder( moisture,protein, fat, ash , crude fibers and carbohydrates) is demonstrated in Table (1). The moisture content of un-fortified bread was higher than fortified bread with 5\% Melissa powder. On the other hand,the fortified bread with 5\% Melissa powder showed increase in ash and crude fibers than that of the un-fortified bread. While carbohydrate, protein and fat values in fortified bread with 5\% Melissa powder nearly returned toward the un-fortified bread values.

Table (2): Active Component of un-fortified and fortified bread with (5,7.5 and $10 \%)$ Melissa powder.

The three types of fortified bread and Melissa powder showed increase in total (phenolic and flavonoid) than the un-fortified bread. While the three types of fortified bread recorded decrease in active component than that of Melissa 
powder.On the other hand, active component recorded the highest value in fortified bread with $10 \%$ Melissa powder than that of fortified bread with $5 \%$ while fortified bread with $10 \%$ nearly returned toward the fortified bread with 7.5\%. The findings are in accordance with Pereira et al.,(2009) who showed that M.officinalis is highly antioxidant and has phenolic compounds.Additionally, .(Sepide Miraj et al.,2017) revealed that The dried Melissa officinalis leaves 11.8 percent of total polyphenol compounds and 0.5 percent of total flavonoid compounds.(Maria Atanassova and Silviya Georgieva,2010) who found that The overall Melissa officinalis phenolic and flavonoid content ranged from( $48.86 \mathrm{mg} \mathrm{GAE} / 100 \mathrm{~g}$ to $45.06 \mathrm{mg} \mathrm{GE} / 100 \mathrm{~g}$ ).

\section{Table (3): Sensory evaluation of pan bread un-fortified and fortified with different levels of Melissa powder.}

The results in Table(3) indicated that bread fortified with 5\% Melissa powder had a non-significant in (taste, odor, valume, texture, tenderness and general acceptability except in external color and internal color and showed bread fortified with $7.5 \%$ MP had a non- significant in taste in comparing with control un-fortified bread,except external color, internal color, odor, volume, texture, tenderness and general acceptability compared with control unfortified bread. While, bread fortified with 10\% MP recorded the lowest significant in external color, internal color, odor, volume, texture, tenderness and general acceptability in compared to the control un-fortified bread.Therefore fortified bread with $5 \%$ recorded the best results in sensory evaluation (general acceptability).

Table (4): Feed intake (FI), feed efficiency ratio (FER) and body weight gain (BWG\%) in normal, intoxicated and treated rats treated with different levels of Melissa powder.

Results in Table (4) endecated that the positive control group was non significantly in the feed efficiency ratio, $\mathrm{BWG} \%$ and FI when compared to normal rats.Comparing treated rats with diet containing fortified bread with $5 \%$ Melissa powder , $7.5 \%$ and $10 \%$ revealed non significant in FI, BWG and FER compared to negative and positive control group rats.Our results agree with(Sief et al.,2015) who cleared that treated animals with Melissa officinalis (MO) shows a marked significant improvement in body weight, feed intake.

Table (5): Serum levels of Triglycerides, Total cholesterol, High density lipoprotein Cholesterol, Low density lipoprotein cholesterol, Very low density lipoprotein Cholesterol in normal, intoxicated and treated rats with different levels of Melissa powder. 
The obtained results in Table(5) showed a marked significant increase in serum total cholesterol, triglycerides, low-density lipoprotein cholesterol and very low-density lipoprotein cholesterol levels and a significant reduced in serum high-density lipoprotein cholesterol levels in positive rats compared to normal rats.Comparing untreated rats with those treated with $(5,7.5,10 \%)$ bread fortified with MP revealed a marked significant decrease in serum levels of TC, TG, LDL and VLDL and significant increase in serum HDL which nearly returned toward the normal levels. Our results agreed with(Bolkent $\boldsymbol{e}$ al., 2005) Melissa officinalis $L$ (MO) admin decreased levels of serum total cholesterol, total lipid.Additionally, (Pereira et al., 2009\&Ashtiyani et al., 2011) found that reducing cholesterol involves reducing its excretion, and inhibiting its synthesis and absorption. The officinalis also suggested that it includes phenolic alkaloids among the materials that can impede the synthesis of cholesterol. MO is a perennial herb of the Lamiaceae family that has been shown to modulate the serum lipid profile.( Parisa Jandaghi et al.,2016).In another study,confirmed that the present results showed that toxicity rats caused by $\mathrm{KbrO} 3$ have substantial rises in TG, TC, and LDLc serum levels, and decreased HDL-c serum levels (Moller and Wallin, 1998). Fortified with MO proved to be as a rich source of antioxidants and active compounds, and can be beneficial in the reversal of LDL-c serum levels with borderline hyperlipidemia..( Parisa Jandaghi et al.,2016).

Table (6): Kidney function in normal, intoxicated and treated rats treated with different levels of Melissa powder.

Data in Table(6) showed that positive control group have significant elevations in serum levels of kidney function compared to normal control rats.In fed contrast, rats fed on bread fortified with $\mathrm{MP}(5 \%, 7.5 \%$ and $10 \%)$ had expressively reduced serum levels of kidney function in comparison to intoxicated positive rats. While there was non significant changes in uric acid and creatinine between treated groups and normal rats. The present result is in agreement with Khan et al. (2011) \&Shelbaya et al. (2014) who showed that $\mathrm{KBrO}_{3}$-intoxicated caused substantial changes in serum kidney function levels compared to negative control group. Another study by Sief et al.,(2015) revealed that In all parameters of kidneys tested, Melissa officinalis (MO) resulted in a pronounced ameliorating effect.

Table (7) Liver function in normal, intoxicated and treated rats treated with different levels of Melissa powder.

Results of alanine amino transferase, aspartate amine transaminase and alkaline phosphatase enzymes of rats are presented in Table(7).It has been found that ALT, AST and ALP of positive control rats were significant increase, in comparison to negative control group.On the other hand, treated 
groups fed on bread fortified with MP $(5 \%, 7.5 \%$ and $10 \%)$ had significantly decreased in ALT , AST and ALP comparison to $\mathrm{KBro}_{3}$ - intoxicated group.Our results agree with Dastmalchi et al.,( 2008) who cleared that antioxidant components and scavenging effects, melissa officinalis $L$ may improve antioxidant defensive activity and reduce oxidant stress and AST in Al workers.Also Ali et al.,(2014) cleared that the liver enzyme production in the treatment groups receiving Melissa officinalis (MO) had decreased liver enzyme levels. Schulz et al.,( 2004) reported that m.officinalis had a diminishing effect on hepatic enzyme activity in treatment groups. Because of its antioxidant properties, polyphenolic compounds can neutralize free radicals and inhibit their destructive effects.Another study by Bolkent et al,(2005) found that previous experiments and research conducted suggested that $\mathrm{M}$. officinalis (MO) may lower liver function, and was effective in improving lever function and treating liver disease.Also Xufeng Tao et al.,(2016) results showed that total flavonoids (TFs) reduced serum AST, ALT and improved hepatic histopathology.

Table (8) Serum levels of SOD,CAT and GPX enzymes in normal ,KBro ${ }^{-}$- intoxicated and intoxicated rats treated with different levels of Melissa powder.

Table(8) shows a marked significant decrease in serum antioxidant enzymes (superoxide dismutase, catalase and glutathione peroxidase) in positive control rats $\left(\mathrm{Kbro}_{3}\right.$ intoxicated) compared to negative rats.In comparison to the treated $\mathrm{KBro}_{3}$ intoxicated rats with(5\%, $7.5 \%$ and $\left.10 \%\right)$ bread fortified with MP caused significant increase in serum activity SOD , CAT and GPX enzymes.Our results agree with Dastmalchi et al.,(2008) who cleared that Melissa officinalis $L$ infusion improves catalase plasma levels, SOD, and GPX.

Table (9) Serum levels of MDA, GSH and TAC in normal, intoxicated and treated rats with different levels of Melissa powder.

Results in Table(9) showed significant decrease in serum glutathione(GSH) and total antioxidant capacity(TAC) levels compared with those of the normal rats.Treated $\mathrm{Kbro}_{3}$ intoxicated groups $\left(\mathrm{G}_{3}, \mathrm{G}_{4}\right.$ and $\left.\mathrm{G}_{5}\right)$ have significant increase and ameliorate in serum of GSH and TAC levels compared with those of the untreated Kbro3 intoxicated rats. While, results shows a marked significant increase in serum malondialdehyde (MDA) level comparing with normal rats.In contrast,groups fed on supplemented diet with $(5 \%, 7.5 \%$ and 10\%)MP had significantly decreased serum levels of(MDA) when compared to positive rats. Our results agree with Davood Fazli et al.,(2012) who stated that using Melissa officinalis infusion resulted in a significant elevations in (TAC) serum levels.Also Xufeng Tao et al.,(2016) said that total 
flavonoids TFs significantly reduced malondialdehyde (MDA). .( Xufeng Tao et al.,2016) showed that complete flavonoids (TFs) improved Glutathione STransferase (GST) protein levels to boost oxidative stress.

Table (10) activity of SOD ,CAT and GPX enzymes in liver tissues of negative, intoxicated and treated groups with different levels of Melissa powder.

Table(10) shows a marked significant reduced in the levels of antioxidant SOD, CAT and GPX enzymes in liver tissues of positive control group compared to the normal control group. Also, there was a significant increase in levels of antioxidant enzymes in treated groups fed on pan bread fortified with $(5 \%, 7.5 \%$ and 10\%)MP compared with those of positive intoxicated rats.Our results is in agreement with Xufeng Tao et al.,(2016) who reported that Total flavonoids TFs significantly increased enzymes of superoxide dismutase ( SOD) and glutathione peroxidase (GSH-Px), indicating that oxidative stress was reduced by TFs.

Table (11) levels of MDA and GSH in liver tissues of negative,intoxicated and treated groups with different levels of Melissa powder.

Comparing positive control group with negative control group the present results showed a marked significant elevations in MDA and reduced in GSH contents in liver tissues homogenates(Table 11). Treated groups fed on pan bread fortified with $(5 \%, 7.5 \%$ and 10\%)MP caused significant reduced in MDA and elevations in GSH content in liver tissues homogenates compared to those of positive intoxicated control group. Our results agreed with Bolkent et al.,( 2005)who stated that officinalis admin increased levels of glutathione in the the liver tissue .Additionally, Vasques et al.,(2016) found that total flavonoids(TFs) were found to increase Glutathione S-Transferase (GST) levels and liver tissue levels.Another study, confirmed that the most important antioxidants are the polyphenolic compounds (Pyo et al., 2004). antioxidants compounds, particularly flavonoids, have a protective effects on hepatic damage from free radicals and liver toxins (Yoshikava et al.,2003).

\section{Histopathological Examinations}

\section{Examination of liver Histopathologically:}

Rat's liver at negative rats $\left(\mathbf{G}_{\mathbf{1}}\right)$ showing normal histological architecture of hepatic lobule from central vein and hepatocytes (Fig. 1). On the other hand, examined sections from Control Positive $\left(\mathbf{G}_{2}\right)$ revealed cytoplasmic vacuolization of hepatocytes, focal hepatic necrosis associated with inflammatory cells infiltration (Fig. 2) and portal inflammatory cells infiltration. However, rat's liver of Bread fortified with( $\mathbf{5 \%}) \mathbf{M P}\left(\mathbf{G}_{3}\right)$ revealed improved picture, examined sections showed slight cytoplasmic 
vacuolization of hepatocytes, and small focal hepatic necrosis associated with inflammatory cells infiltration (Fig. 3). Moreover, rat's liver of Bread fortified with $(\mathbf{7 . 5 \%})$ MP $\left(\mathbf{G}_{4}\right)$ showed regression of the histopathological changes, examined sections revealed only cytoplasmic vacuolization of hepatocytes (Fig. 4). Meanwhile, marked improved changes was observed in liver of rats fed Bread fortified with( $\mathbf{1 0 \%})$ MP $\left(\mathbf{G}_{5}\right)$, the liver restored the normal histological structure without histopathological alterations (Fig. 5). Our results agree with (Gokcimen et al.,2007)who stated that the liver portions of animals treated with Melissa officinalis(MO) showed changes in histological picture.Additionally, ( Rosety et al.,2005) revealed that antioxidants are the foremost system of defense that limits the toxicity associated with free radicals. The cellular antioxidant status also determines the susceptibility to oxidative damage and is usually altered to oxidative stress. (Sief et al.,2015) also found that a photomicrograph showing normal central vein and normal hepatocytes in control rat's liver. In the rats treated with Melissa officinalis(MO) the liver sections showed normal lymphocyte parenchyma and normal focal aggregation.. ( Shah et al.,2013)reported that total flavonoids (TFs) were defensive by decreasing coagulation necrosis with significant infiltration of inflammatory cells in the liver.Another study by(Medina and Moreno-Otero, 2005) revealed that the findings obtained from the histopathological study, which showed that the injection of $\mathrm{KBrO}_{3}$ caused morphopathological changes in the liver including inflammation of hepatic sinusoid, vacuolization of hepatocytes and necrosis of scattered hepatocytes, were verified.

\section{Conclusion}

In conclusion The effects of diet that include fortified pan bread with $10 \%$ MP had a good effect and exhibited improvement in kidney and liver functions against induced by potassium bromate $\left(\mathrm{KBrO}_{3}\right)$. The consisting of $10 \%$ fortified bread MP provide the best improvement in biochemical measurements and histological structure.Hence, regular intake of MP for enriching food product as functional foods may help to improve health status.

Table (1): Chemical analysis of un-fortified and fortified bread with 5\% Melissa powder.

\begin{tabular}{|c|c|c|c|c|c|c|c|}
\hline Content (\%) & Moisture & Protein & Fat & Ash & $\begin{array}{c}\text { Crude } \\
\text { fibers }\end{array}$ & $\begin{array}{c}\text { Total } \\
\text { Carbohydrates }\end{array}$ & Total \\
\hline $\begin{array}{c}\text { Samples } \\
\text { un-fortified bread } \\
\text { Control }\end{array}$ & 8.449 & 11.190 & 6.669 & 0.970 & 0.69 & 72.032 & 100 \\
\hline $\begin{array}{c}\text { fortified bread } \\
\text { with 5\% Melissa } \\
\text { powder }\end{array}$ & 7.917 & 11.369 & 6.099 & 1.445 & 1.10 & 72.07 & 100 \\
\hline
\end{tabular}


Table (2):Active Component of un-fortified and fortified bread with (5,7.5 and $10 \%)$ Melissa powder.

\begin{tabular}{|c|c|c|}
\hline $\begin{array}{ll}\text { Samples } & \text { Content }(\%) \\
\end{array}$ & $\begin{array}{l}\text { Total phenolic } \\
\text { (mg/g) }\end{array}$ & $\begin{array}{l}\text { Total flavonoid } \\
(\mathrm{mg} / \mathrm{g})\end{array}$ \\
\hline un-fortified bread Control & 1.561 & 0.16 \\
\hline $\begin{array}{c}\text { fortified bread with (5\%) Melissa } \\
\text { powder }\end{array}$ & 1.701 & 1.29 \\
\hline $\begin{array}{c}\text { fortified bread with (7.5\%) Melissa } \\
\text { powder }\end{array}$ & 2.021 & 1.84 \\
\hline $\begin{array}{c}\text { fortified bread with (10\%) Melissa } \\
\text { powder }\end{array}$ & 2.456 & 1.96 \\
\hline Melissa powder & 44.674 & 14.01 \\
\hline
\end{tabular}

Table (3): Sensory evaluation of pan bread un-fortified and fortified with different levels of Melissa powder.

\begin{tabular}{|c|c|c|c|c|c|c|c|c|}
\hline Samples & $\begin{array}{c}\text { External } \\
\text { Color } \\
5\end{array}$ & $\begin{array}{c}\text { Internal } \\
\text { Color } \\
5\end{array}$ & $\begin{array}{c}\text { Taste } \\
10\end{array}$ & $\begin{array}{c}\text { Odor } \\
5\end{array}$ & $\begin{array}{c}\text { Volume } \\
5\end{array}$ & $\begin{array}{c}\text { Texture } \\
5\end{array}$ & $\begin{array}{c}\text { Tenderness } \\
5\end{array}$ & $\begin{array}{c}\text { General } \\
\text { Acceptability } \\
10\end{array}$ \\
\hline $\begin{array}{l}\text { Control (un- } \\
\text { fortified bread) }\end{array}$ & $4.83^{\mathrm{a}} \pm 0.41$ & $4.83^{\mathrm{a}} \pm 0.41$ & $8.41^{\mathrm{a}} \pm 2.20$ & $4.75^{\mathrm{a}} \pm 0.41$ & $4.83^{\mathrm{a}} \pm 0.40$ & $4.91^{\mathrm{a}} \pm 0.20$ & $4.75^{\mathrm{a}} \pm 0.41$ & $9.50^{\mathrm{a}} \pm 0.83$ \\
\hline $\begin{array}{l}\text { Bread fortified } \\
\text { with( } 5 \%) \quad \text { MP }\end{array}$ & $3.70^{b} \pm 0.40$ & $3.36^{\mathbf{b}} \pm 0.43$ & $7.33^{\mathbf{a b}} \pm 2.16$ & $4.00^{\mathbf{a b}} \pm 0.31$ & $4.66^{\mathrm{a}} \pm 0.51$ & $4.40^{\mathrm{a}} \pm 0.64$ & $4.15^{\mathrm{a}} \pm 0.36$ & $8.25^{\mathrm{a}} \pm 1.08$ \\
\hline $\begin{array}{l}\text { Bread fortified } \\
\text { with }(7.5 \%) \text { MP }\end{array}$ & $2.83^{C_{ \pm}}=0.41$ & $2.66^{\mathbf{c}} \pm 0.51$ & $6.25^{\mathbf{a b}} \pm 1.75$ & $3.33^{\mathbf{b c}} \pm 0.51$ & $2.83^{\mathbf{b}} \pm 0.40$ & $3.00^{b} \pm 0.89$ & $3.16^{b} \pm 0.75$ & $6.25^{b} \pm 1.17$ \\
\hline $\begin{array}{l}\text { Bread fortified } \\
\text { with(10\%) MP }\end{array}$ & $2.08^{d} \pm 0.66$ & $1.75^{\mathrm{d}_{ \pm 0}}+61$ & $5.41^{\mathbf{b}} \pm 1.46$ & $3.00^{c} \pm 1.09$ & $2.41^{b} \pm 1.02$ & $2.50^{b} \pm 1.09$ & $2.50^{\mathbf{b}} \pm 0.89$ & $5.30^{\mathbf{b}} \pm 1.42$ \\
\hline LSD & 0.58 & 0.60 & 2.31 & 0.79 & 0.77 & 0.94 & 0.78 & 1.38 \\
\hline
\end{tabular}

Means with different letters in each column are significantly different at $\mathbf{p}<\mathbf{0 . 0 5}$.

SD:Standard Deviation

Table (4). nutritional parameters in normal, intoxicated and treated rats with different levels of Melissa powder.

\begin{tabular}{|c|c|c|c|}
\hline Parameters & FI (g/day) & FER(g) & BWG (\%) \\
\hline Croups & $18.51^{\mathrm{a}} \pm 0.51$ & $0.04^{\mathrm{a}} \pm 0.02$ & $15.01^{\mathrm{a}} \pm 5.43$ \\
\hline Control NegativeG $_{\mathbf{1}}$ & $18.81^{\mathrm{a}} \pm 0.44$ & $0.06^{\mathrm{a}} \pm 0.01$ & $23.23^{\mathrm{a}} \pm 6.23$ \\
\hline $\begin{array}{c}\text { Bread fortified with (5\%) } \\
\text { MP G }_{\mathbf{3}}\end{array}$ & $18.79^{\mathrm{a}} \pm 0.37$ & $0.04^{\mathrm{a}} \pm 0.02$ & $15.94^{\mathrm{a}} \pm 6.51$ \\
\hline $\begin{array}{c}\text { Bread fortified with } \\
\text { (7.5\%) MP G }\end{array}$ & $18.72^{\mathrm{a}} \pm 0.36$ & $0.05^{\mathrm{a}} \pm 0.03$ & $16.66^{\mathrm{a}} \pm 10.71$ \\
\hline $\begin{array}{c}\text { Bread fortified with } \\
\left(\mathbf{1 0 \% )} \mathbf{M P}_{\mathbf{5}}\right.\end{array}$ & $18.55^{\mathrm{a}} \pm 0.61$ & $0.03^{\mathrm{a}} \pm 0.01$ & $14.24^{\mathrm{a}} \pm 3.64$ \\
\hline LSD & 0.71 & 0.03 & 10.41 \\
\hline
\end{tabular}

Means with different letters in each column are significantly different at $\mathrm{p}<0.05$

SD:Standard Deviation. 
Table (5): Serum levels of Triglycerides, Total cholesterol, High density lipoprotein Cholesterol, Low density lipoprotein cholesterol, Very low density lipoprotein Cholesterol in normal, intoxicated and treated rats with different levels of Melissa powder.

\begin{tabular}{|c|c|c|c|c|c|}
\hline $\begin{array}{l}\text { Variables } \\
\text { Groups }\end{array}$ & $\begin{array}{c}\mathrm{TC} \\
(\mathrm{mg} / \mathrm{dl})\end{array}$ & $\begin{array}{c}\text { TG } \\
(\mathrm{mg} / \mathrm{dl})\end{array}$ & $\begin{array}{c}\text { HDL } \\
(\mathrm{mg} / \mathrm{dl})\end{array}$ & $\begin{array}{c}\text { LDL } \\
(\mathrm{mg} / \mathrm{dl})\end{array}$ & $\begin{array}{l}\text { VLDL } \\
(\mathrm{mg} / \mathrm{dl})\end{array}$ \\
\hline $\begin{array}{c}\text { Control } \\
\text { NegativeG }_{1} \\
\end{array}$ & $101.49^{\mathrm{d}} \pm 23.87$ & $113.35^{\mathrm{c}} \pm 11.09$ & $52.46^{\mathrm{a}} \pm 1.51$ & $26.36^{d} \pm 23.54$ & $22.67^{c} \pm 2.21$ \\
\hline $\begin{array}{c}\text { Control } \\
\text { PositiveG } \\
\end{array}$ & $282.10^{\mathrm{a}} \pm 18.14$ & $222.92^{\mathrm{a}} \pm 25.74$ & $45.67^{c} \pm 2.65$ & $191.83^{\mathrm{a}} \pm 16.85$ & $44.60^{\mathrm{a}} \pm 5.17$ \\
\hline $\begin{array}{c}\text { Bread } \\
\text { fortified with( } \\
5 \%) \mathrm{MP} \mathrm{G}_{\mathbf{3}} \\
\end{array}$ & $252.40^{\mathrm{ab}} \pm 18.42$ & $211.90^{\mathrm{ab}} \pm 13.93$ & $48.79^{\mathrm{b}} \pm 1.68$ & $161.22^{\mathrm{b}} \pm 19.39$ & $42.38^{\mathrm{ab}} \pm 2.78$ \\
\hline $\begin{array}{c}\text { Bread } \\
\text { fortified with } \\
(7.5 \%) \mathrm{MP} \mathrm{G}_{4} \\
\end{array}$ & $222.02^{\mathrm{b}} \pm 19.48$ & $189.87^{\mathrm{b}} \pm 25.95$ & $50.62^{\mathrm{ab}} \pm 0.81$ & $133.43^{\mathrm{b}} \pm 16.20$ & $37.97^{\mathrm{b}} \pm 5.19$ \\
\hline \begin{tabular}{|c|} 
Bread \\
fortified with( \\
$10 \%)$ MP $G_{5}$
\end{tabular} & $152.60^{c} \pm 23.70$ & $121.85^{\mathrm{c}} \pm 21.58$ & $51.46^{\mathrm{a}} \pm 0.93$ & $76.76^{c} \pm 21.33$ & $24.37^{\mathrm{c}} \pm 4.31$ \\
\hline LSD & 31.47 & 31.03 & 2.49 & 29.63 & 6.22 \\
\hline
\end{tabular}

Means with different letters in each column are significantly different at $\mathrm{p}<0.05$

SD:Standard Deviation.

Table (6): Kidney function in normal, intoxicated and treated rats with various levels from Melissa powder.

\begin{tabular}{|c|c|c|c|}
\hline Groups & $\begin{array}{c}\text { Uric acid } \\
(\mathbf{m g} / \mathbf{d l})\end{array}$ & $\begin{array}{c}\text { Urea } \\
(\mathbf{m g} / \mathbf{d l})\end{array}$ & $\begin{array}{c}\text { Creatinine } \\
(\mathbf{m g} / \mathbf{d l})\end{array}$ \\
\hline Control NegativeG $_{\mathbf{1}}$ & $4.34^{\mathrm{d}} \pm 0.81$ & $30.45^{\mathrm{d}} \pm 4.62$ & $0.55^{\mathrm{d}} \pm 0.04$ \\
\hline Control PositiveG $_{\mathbf{2}}$ & $10.41^{\mathrm{a}} \pm 1.97$ & $91.60^{\mathrm{a}} \pm 13.41$ & $1.20^{\mathrm{a}} \pm 0.13$ \\
\hline $\begin{array}{c}\text { Bread fortified with (5\%) } \\
\text { MP G}_{\mathbf{3}}\end{array}$ & $7.96^{\mathrm{b}} \pm 0.25$ & $66.37^{\mathrm{b}} \pm 4.40$ & $0.92^{\mathrm{b}} \pm 0.10$ \\
\hline $\begin{array}{c}\text { Bread fortified with } \\
\text { (7.5\%) MP G }\end{array}$ & $6.74^{\mathrm{bc}} \pm 0.28$ & $55.09^{\mathrm{c}} \pm 3.67$ & $0.73^{\mathrm{c}} \pm 0.07$ \\
\hline $\begin{array}{c}\text { Bread fortified with } \\
\text { (10\%) MP } \mathbf{G}_{\mathbf{5}}\end{array}$ & $5.35^{\mathrm{cd}} \pm 0.40$ & $45.04^{\mathrm{c}} \pm 2.82$ & $0.60^{\mathrm{cd}} \pm 0.03$ \\
\hline LSD & 1.48 & 10.48 & 0.13 \\
\hline
\end{tabular}

Means with different letters in each column are significantly different at $\mathrm{p}<0.05$.

SD:Standard Deviation. 
Table (7) Serum levels of Alanine Amine Transaminase, Aspartate Amine Transaminase, Alkaline Phosphatase in normal, intoxicated and treated rats with different levels of Melissa powder.

\begin{tabular}{|c|c|c|c|}
\hline $\begin{array}{c}\text { Parameters } \\
\text { Groups }\end{array}$ & $\begin{array}{c}\text { ALT } \\
(\mathbf{U} / \mathbf{L})\end{array}$ & $\begin{array}{c}\text { AST } \\
(\mathbf{U} / \mathbf{L})\end{array}$ & $\begin{array}{c}\text { ALP } \\
(\mathbf{U} / \mathbf{L})\end{array}$ \\
\hline Control NegativeG $_{\mathbf{1}}$ & $33.07^{\mathrm{e}} \pm 3.36$ & $107.03^{\mathrm{d}} \pm 13.65$ & $194.50^{\mathrm{e}} \pm 16.54$ \\
\hline Control PositiveG $_{\mathbf{2}}$ & $130.07^{\mathrm{a}} \pm 11.99$ & $242.67^{\mathrm{a}} \pm 14.55$ & $584.25^{\mathrm{a}} \pm 27.65$ \\
\hline $\begin{array}{c}\text { Bread fortified with } \\
\left(\mathbf{5 \% )} \mathbf{M P}_{\mathbf{3}}\right.\end{array}$ & $93.49^{\mathrm{b}} \pm 10.92$ & $188.07^{\mathrm{b}} \pm 20.24$ & $445.50^{\mathrm{b}} \pm 28.75$ \\
\hline $\begin{array}{c}\text { Bread fortified with } \\
\left(\mathbf{7 . 5 \% )} \mathbf{M P ~ G}_{\mathbf{4}}\right.\end{array}$ & $72.77^{\mathrm{c}} \pm 7.63$ & $171.65^{\mathrm{b}} \pm 7.74$ & $366.50^{\mathrm{c}} \pm 13.47$ \\
\hline $\begin{array}{c}\text { Bread fortified with } \\
\left(\mathbf{1 0 \% )} \mathbf{M P} \mathbf{G}_{\mathbf{5}}\right.\end{array}$ & $59.88^{\mathrm{d}} \pm 3.75$ & $136.17^{\mathrm{c}} \pm 11.50$ & $283.50^{\mathrm{d}} \pm 22.94$ \\
\hline LSD & 12.55 & 21.32 & 34.19 \\
\hline
\end{tabular}

Means with different letters in each column are significantly different at $\mathrm{p}<0.05$.

SD:Standard Deviation.

Table (8) Serum levels of superoxide dismutase , catalase and glutathione peroxidase enzymes in normal, intoxicated and in different treated groups of Melissa powder.

\begin{tabular}{|c|c|c|c|}
\hline $\begin{array}{c}\text { Parameters } \\
\text { Groups }\end{array}$ & $\begin{array}{c}\text { SOD } \\
(\mathbf{u} / \mathbf{m l})\end{array}$ & $\begin{array}{c}\text { CAT } \\
(\mathbf{n g} / \mathbf{m l})\end{array}$ & $\begin{array}{c}\text { GPX } \\
(\mathbf{u} / \mathbf{m l})\end{array}$ \\
\hline Control NegativeG $_{\mathbf{1}}$ & $154.50^{\mathrm{a}} \pm 6.65$ & $10.37^{\mathrm{a}} \pm 0.72$ & $375.75^{\mathrm{a}} \pm 30.44$ \\
\hline Control PositiveG $_{\mathbf{2}}$ & $28.50^{\mathrm{e}} \pm 4.43$ & $0.64^{\mathrm{e}} \pm 0.21$ & $60.25^{\mathrm{e}} \pm 17.46$ \\
\hline $\begin{array}{c}\text { Bread fortified with } \\
\left(\mathbf{5 \% )} \mathbf{M P ~ G}_{\mathbf{3}}\right.\end{array}$ & $46.00^{\mathrm{d}} \pm 4.54$ & $4.25^{\mathrm{d}} \pm 0.54$ & $140.50^{\mathrm{d}} \pm 7.85$ \\
\hline $\begin{array}{c}\text { Bread fortified with } \\
\left(\mathbf{7 . 5 \% )} \mathbf{M P ~ G}_{\mathbf{4}}\right.\end{array}$ & $66.00^{\mathrm{c}} \pm 5.77$ & $6.97^{\mathrm{c}} \pm 0.43$ & $210.50^{\mathrm{c}} \pm 16.54$ \\
\hline $\begin{array}{c}\text { Bread fortified with } \\
\left(\mathbf{1 0 \% )} \text { MP } \mathbf{G}_{\mathbf{5}}\right.\end{array}$ & $110.25^{\mathrm{b}} \pm 18.11$ & $8.02^{\mathrm{b}} \pm 0.21$ & $285.00^{\mathrm{b}} \pm 9.09$ \\
\hline LSD & 14.23 & 0.71 & 27.37 \\
\hline
\end{tabular}

Means with different letters in each column are significantly different at $\mathrm{p}<0.05$.

SD:Standard Deviation. 
Table (9): Serum levels of malondialdehyde, glutathione and total antioxidant capacity in normal, intoxicated and treated rats with different levels of Melissa powder.

\begin{tabular}{|c|c|c|c|}
\hline $\begin{array}{c}\text { Parameters } \\
\text { Groups }\end{array}$ & $\begin{array}{c}\text { MDA } \\
(\mathbf{n m o l} / \mathbf{m l})\end{array}$ & $\begin{array}{c}\text { GSH } \\
(\mathbf{n g} / \mathbf{m l})\end{array}$ & $\begin{array}{c}\text { TAC } \\
(\mathbf{n g} / \mathbf{m l})\end{array}$ \\
\hline Control NegativeG $_{\mathbf{1}}$ & $1.64^{\mathrm{e}} \pm 0.92$ & $355.00^{\mathrm{a}} \pm 36.39$ & $6.93^{\mathrm{a}} \pm 0.87$ \\
\hline Control PositiveG $_{\mathbf{2}}$ & $26.37^{\mathrm{a}} \pm 1.83$ & $32.25^{\mathrm{e}} \pm 12.61$ & $0.58^{\mathrm{e}} \pm 0.14$ \\
\hline $\begin{array}{c}\text { Bread fortified with } \\
\left(\mathbf{5 \% )} \mathbf{M P}_{\mathbf{3}}\right.\end{array}$ & $19.25^{\mathrm{b}} \pm 1.55$ & $92.00^{\mathrm{d}} \pm 8.64$ & $1.37^{\mathrm{d}} \pm 0.32$ \\
\hline $\begin{array}{c}\text { Bread fortified with } \\
\mathbf{( 7 . 5 \% ) ~ M P ~ G}_{\mathbf{4}}\end{array}$ & $14.06^{\mathrm{c}} \pm 2.87$ & $137.00^{\mathrm{c}} \pm 14.31$ & $2.43^{\mathrm{c}} \pm 0.42$ \\
\hline $\begin{array}{c}\text { Bread fortified with } \\
\left(\mathbf{1 0 \% )} \text { MP } \mathbf{G}_{\mathbf{5}}\right.\end{array}$ & $7.50^{\mathrm{d}} \pm 0.93$ & $234.25^{\mathrm{b}} \pm 39.11$ & $5.83^{\mathrm{b}} \pm 0.51$ \\
\hline LSD & 2.67 & 38.67 & 0.77 \\
\hline
\end{tabular}

Means with different letters in each column are significantly different at $\mathrm{p}<0.05$.

SD:Standard Deviation.

Table (10) Activity of superoxide dismutase, catalase and glutathione peroxidase enzymes in liver tissues of control negative, intoxicated and treated groups with different levels of Melissa powder.

\begin{tabular}{|c|c|c|c|}
\hline $\begin{array}{c}\text { Parameters } \\
\text { Groups }\end{array}$ & $\begin{array}{c}\text { SOD } \\
(\mathbf{u} / \mathbf{m g})\end{array}$ & $\begin{array}{c}\text { CAT } \\
(\mathbf{n g} / \mathbf{m g})\end{array}$ & $\begin{array}{c}\text { GPX } \\
(\mathbf{u} / \mathbf{m g})\end{array}$ \\
\hline Control NegativeG $_{\mathbf{1}}$ & $132.50^{\mathrm{a}} \pm 10.34$ & $9.42^{\mathrm{a}} \pm 0.76$ & $270.25^{\mathrm{a}} \pm 23.08$ \\
\hline Control PositiveG $_{\mathbf{2}}$ & $28.00^{\mathrm{e}} \pm 4.54$ & $0.85^{\mathrm{e}} \pm 0.29$ & $60.00^{\mathrm{e}} \pm 20.83$ \\
\hline $\begin{array}{c}\text { Bread fortified with } \\
\mathbf{( 5 \% )} \mathbf{M P ~ G}_{\mathbf{3}}\end{array}$ & $42.50^{\mathrm{d}} \pm 4.20$ & $2.86^{\mathrm{d}} \pm 1.12$ & $119.50^{\mathrm{d}} \pm 14.93$ \\
\hline $\begin{array}{c}\text { Bread fortified with } \\
\left(\mathbf{7 . 5 \% )} \mathbf{M P ~ G}_{\mathbf{4}}\right.\end{array}$ & $57.25^{\mathrm{c}} \pm 5.31$ & $5.71^{\mathrm{c}} \pm 0.45$ & $166.75^{\mathrm{c}} \pm 13.84$ \\
\hline $\begin{array}{c}\text { Bread fortified with } \\
\left(\mathbf{1 0 \% )} \text { MP } \mathbf{G}_{\mathbf{5}}\right.\end{array}$ & $78.25^{\mathrm{b}} \pm 5.43$ & $8.08^{\mathrm{b}} \pm 0.31$ & $244.25^{\mathrm{b}} \pm 9.81$ \\
\hline LSD & 9.61 & 1.01 & 25.91 \\
\hline
\end{tabular}

Means with different letters in each column are significantly different at $\mathrm{p}<0.05$.

SD:Standard Deviation. 
Table (11) Concentration of malondialdehyde, and glutathione in liver tissues of normal, positive control and treated rats with different levels of Melissa powder.

\begin{tabular}{|c|c|c|}
\hline $\begin{array}{c}\text { Parameters } \\
\text { Groups }\end{array}$ & $\begin{array}{c}\text { MDA } \\
(\mathbf{n m o l} / \mathbf{m g})\end{array}$ & $\begin{array}{c}\text { GSH } \\
(\mathbf{n g} / \mathbf{m g})\end{array}$ \\
\hline Control NegativeG $_{\mathbf{1}}$ & $2.50^{\mathrm{e}} \pm 1.21$ & $258.75^{\mathrm{a}} \pm 28.21$ \\
\hline Control PositiveG $_{\mathbf{2}}$ & $22.81^{\mathrm{a}} \pm 1.21$ & $32.50^{\mathrm{e}} \pm 16.90$ \\
\hline $\begin{array}{c}\text { Bread fortified with } \\
(\mathbf{5 \%}) \mathbf{M P ~ G}_{\mathbf{3}}\end{array}$ & $19.68^{\mathrm{b}} \pm 1.24$ & $72.50^{\mathrm{d}} \pm 6.75$ \\
\hline $\begin{array}{c}\text { Bread fortified with } \\
\text { (7.5\%) MP } \mathbf{G}_{\mathbf{4}}\end{array}$ & $12.60^{\mathrm{c}} \pm 2.89$ & $107.50^{\mathrm{c}} \pm 6.45$ \\
\hline $\begin{array}{c}\text { Bread fortified with } \\
\text { (10\%) MP } \mathbf{G}_{\mathbf{5}}\end{array}$ & $7.26^{\mathrm{d}} \pm 0.91$ & $166.25^{\mathrm{b}} \pm 3.40$ \\
\hline LSD & 2.49 & 23.16 \\
\hline
\end{tabular}

Means with different letters in each column are significantly different at $\mathrm{p}<0.05$.

SD:Standard Deviation.

\section{Examination of liver Histopathologically:}

\begin{tabular}{|c|c|}
\hline liver & Results \\
\hline Hof & $\begin{array}{l}\text { (Fig. 1). Rat's liver at negative control } \\
\text { showing the normal histological } \\
\text { architecture of hepatic lobule (H \& E X } \\
\text { 200). }\end{array}$ \\
\hline 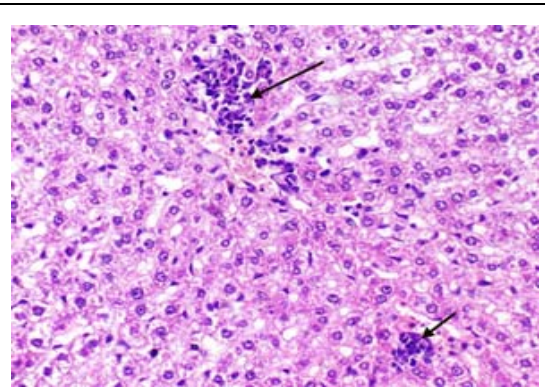 & $\begin{array}{l}\text { (Fig. 2). Rat's liver at positive control } \\
\text { showing focal hepatic necrosis associated } \\
\text { with inflammatory cells infiltration } \\
\text { (short arrow) and portal inflammatory } \\
\text { cells infiltration (long arrow) (H \& E X } \\
\text { 200). }\end{array}$ \\
\hline
\end{tabular}




\begin{tabular}{|c|c|}
\hline 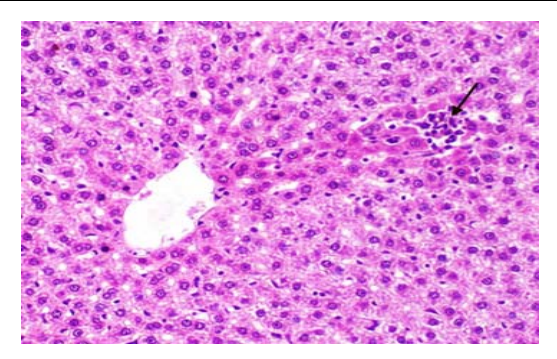 & $\begin{array}{l}\text { (Fig. 3).Rat's liver at rats treated with } \\
5 \% \text { showing small focal hepatic necrosis } \\
\text { associated with inflammatory cells } \\
\text { infiltration (arrow) (H \& E X 200). }\end{array}$ \\
\hline 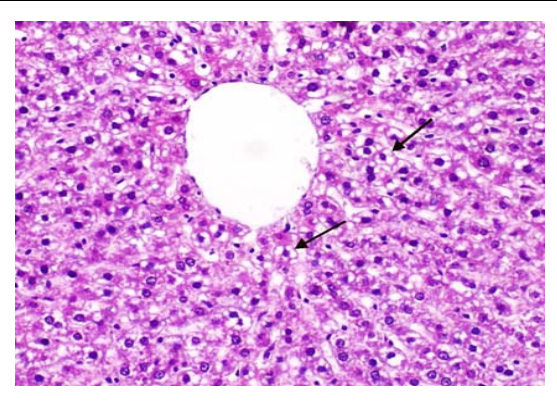 & $\begin{array}{l}\text { (Fig. 4). Rat's liver at rats treated with } \\
7.5 \% \text { showing cytoplasmic vacuolization } \\
\text { of hepatocytes (arrow) (H \& E X 200). }\end{array}$ \\
\hline 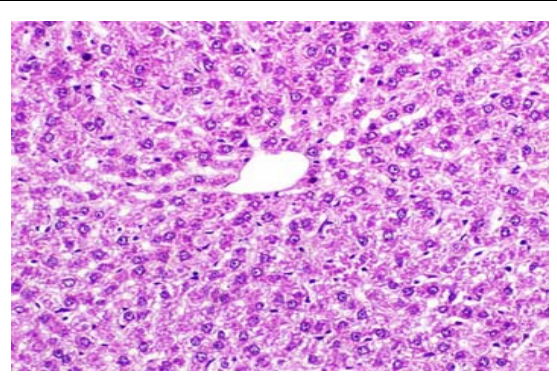 & $\begin{array}{l}\text { (Fig. 5).Rat's liver at rats treated with } \\
10 \% \quad \text { showing no histopathological } \\
\text { alterations. Note normal hepatic lobule } \\
\text { (H \& E X 200). }\end{array}$ \\
\hline
\end{tabular}




\section{References}

-Abd El-latif, B.M. (1990).Improvement of some bakery products. [dissertation]. Zagazig, Faculty of Agriculture, Food Tech. Zagazig University, Egypt.

- Abdelghafor ,R.F. ; Mustafa ,A.I. ; Ibrahim ,A.M.H. and Krishnan, P.G.(2011). Quality of bread from composite flour of sorghum and hard white winter wheat. Advance Journal of Food Science and Technology .3(1): 9-15.

-Aebi, H. (1984). Catalase in vitro. Methods Enzymol., 105:121-126.

-Albro, P.W.; Corbett, J.T. and Schroeder, J.L. (1986). Application of the thiobarbiturate assay to the measurement of lipid peroxidation products in microsomes. J. Biochem. Biophys. Methods, 13:185-194.

-Ali ,Z.; Saeed ,C. A.; Soheila, T and Fateme, R.(2014). Comparison between effects of different doses of Melissa officinalis and atorvastatin on the activity of liver enzymes in hypercholesterolemia rats. AJP,. 4,( 1):15-23.

-A.O.A.C.(2003).Association of Official Analytical Chemists International $18^{\text {th }}$ ed.,Arlington,Virginia,USA .

-Ashtiyani, S.C.; Zarei ,A.; Taheri ,S and Rasekh, F.( 2011).The effects of Portulaca Oleracea extract on induced hypercholesteroleomia in rats.ZJRMS, 13: 20-24.

-Atanassova ,M and Christova-Bagdassarian, V. (2009). Determination of tannins content by titrimetric method for comparison of different plant species. Journal of the University of Chemical Technology and Metallurgy, 44,( 4) : 413-415.

- Bancroft ,J.D.; Suvarna,K and Layton,C.( 2012). Bancroft's theory and practice of histological techniques. $7^{\text {th }}$ ed. E book ISBN. 978-0-7020-50325039.

- Bartels, H. and Bohmer, M. (1971).Creatinine standard and measurement of serum creatinine with picric acid. Clin. Chem.; Acta. 32:81.

- Belfield, A. and Goldberg, D.M. (1971). Alkaline Phosphatase Colorimetric Method". J. of Enzyme. (12): 561.

-Beutler, E.; Duron, O. and Kelly, B.M. (1963). Improved method for the determination of blood glutathione. J. Lab. Clin. Med., 61:882-888.

- Bolkent, S.; Yanardag,R.; Karabulut-Bulan,O and Yesilyaprak,B (2005). Protective role of Melissa officinalis L. extract on liver of hyperlipidemic rats: A morphological and biochemical study. J. Ethnopharmacol., 99: 391-398.

-Capecka, E.; Mareczek, A and Leja, M.(2005). Antioxidant activity of fresh and dry herbs of some Lamiaceae species. Food Chem.;93:223-226. 
- Chapman, D.G.; Castilla,R. and Champell, J.A.(1959).Evaluation of protein efficiency ratio,Can.J.Biochem.Physiol.37:679-686.

- Dastmalchi, K.; Dorman,H.J.D .; Oinonen,P.P .; Darwis,Y .; Laakso,I and Hiltunen, $R$ (2008). Chemical composition and In vitro antioxidative activity of a lemon balm (Melissa officinalis L.) extract. LWT-Food Sci. Technol., 41: 391-400.

-Davood, F.; Ali ,A. M.; Ali, A. P.;Homayon, S.; Akbar, Z.; Kobra ,R and Mohammad, A. (2012). Effects of Melissa officinalis L. on Oxidative Status and Biochemical Parameters in Occupationally Exposed Workers to Aluminum: A Before after Clinical Trial. International Journal of Pharmacology, 8: 455458.

-Deepa ,V.S.; Kumar, P.S.; Latha, S.; Selvamani, Pand Srinivasan ,S. (2009). Antioxidant studies on the ethanolic extract of Commiphora spp., African Journal of Biotechnology,. 8(8), : 1630-1636.

-Draper, H. and Hadley, M. (1990): Malondialdehyde determination as index of lipid peroxidation. Methods Enzymol., 186: 421-431.

-Emamghorishi, $M$ and Talebianpour ,M.S. (2009).Antidepressant effect of Melissa officinalis in the forced swimming test. DARU J Pharm Sci, 17: 42-47.

- Fossati, P.; Prencipe, L. and Berti, G. (1980). Enzymatic colorimetric method of determination of uric acid in serum. Clin. Chem. 26 (2): 227-273.

-Fried wald, W. T.; Leve, R. I. and Fredrickson‘ D. S. (1972). Estimation of the concentration of low-density lipoprotein separation by three different methods . Cli. Chem.; 18: 499-502.

-Gokcimen, A.; Gulle, K and Demirin, H.( 2007). Effects of diazinon at different doses on rat liver and pancreas tissues. Pesticide Biochemistry and Physiology.;87:103-108.

-Has, X.; Shen, T and Lou, H. (2007). Dietary polyphenols and their biological significance. International Journal of Molecular Sciences, 8, : 950988.

-Hasani,R. S.; Larijani,B and Abdollahi,M .( 2009). A systematic review of the potential herbal sources of future drugs effective in oxidant-related diseases. Inflamm. Allergy Drug Targets, 8: 2-10.

-Hayam,A.EA.(2020).Ameliorative Effect of Melissa Officinalis on Hepatic Toxicity in Rats.Egyptian J.of Nutrition.1(35):ISSN 1687- 1235.

-Hissin, P.L. and Hiff, R. (1976). A fluorometric method for determination of oxidized and reduced glutathione in tissues. Anal. Biochem., 74 (1): 214-226.

-Hyunjin Noh and Hunjoo Ha.(2011). Reactive Oxygen Species and Oxidative Stress. Contrib Nephrol. Basel, Karger, (170): 102-112. 
-Ibrahim S.S.(1999):Comparative evaluation of two different forms of dietary fiber on atherosclerosis in rats.MSc.Thes is Home Economics, Helwan Univ.Nutrition and Food Science Dept.,P16.

- Jastrzebska-Stojko, Z.; Stojko, R.; Rzepecka-Stojko ,A.; Kabała-Dzik,A and Stojko, J.(2013). Biological activity of propolis-honey balm in the treatment of experimentally-evoked burn wounds. Molecules.18:14397-14413.

-Kakkor, P.; Das, B. and Viswanathan, P.N. (1984). A modified spectrophotometric assay of superoxide dismutase. Ind. J. Biochem.Biophyso., 21: 130-132.

-Khan, R.A.; Khan, M.R.; Sahreen, S.; Shah, N.A.; Bokhari, J.;Shabbir, M.; Rashid, R. and Jan, S. (2011). Protective effects of Launaea procumbens against KbrO3-induced hepatic serum marker enzymes. African J. of Pharm. And Pharmac., 5 (23): 2639-2641.

-Khan,N.and Sultana,S.(2004).Abrogation of potassium bromate induced renal oxidative stress and tumor promotion response by soy isoflavones in wistar rats.Toxicology 201(1-3):173-184.

- Krajcovicova-Kudlackova, M.; Valachovicova, M. .; Mislanova ,C. and Pribiojova, J. (2012). Antioxidative vitamins and oxidative lipid and DNA damage in relation to nutrition. Oxid. Antioxid. Med.Sci., 1(2): 147-151.

-Lopes-Virella, M. F.;Stone, S.;Ellis, S. and Collwellm, J. A. (1977).Cholesterol determination in high-density lipoproteins separated by three different methods. Clin. Chem.; 23 (5): 882-893.

- Marsch, W.H.; Fingerhut, B.and Miller,H. (1965).Automated and manual direct methods for the determination of blood urea.Clin.Chem.11:624-27.

-Maria Atanassova and Silviya Georgieva.(2010). Comparative Polyphenol Composition and Antioxidant Capacity Of The Bulgarian Plants (Dry Herbs). Electronic Journal of Environmental Agricultural and Food Chemistry,9 (9), :1514-1523.

- Mates, M.J.; Ortiz-Lombardia, M.; Boitel, B.; Haouz, A.; Tello, D.; Susin, S.A.; Penninger, J.; Kroemer, G and Alzari, P.M. (2002). The crystal structure of the mouse apoptosis induced factor AIF. Nature Structural and Molecular Biology, 9: 44-446.

-Medina, J. and Moreno-Otero, R. (2005). Pathophysiological basis for antioxidant therapy in chronic liver disease. Drugs, 65 (17): 2445-2461.

-Mimica-Dukic, N.; Bozin, B.; Sokovic ,M and Simin, N. (2004). Antimicrobial and antioxidant activities of Mentha officinalis L. (Lamiaceae) 78elissa781 oil. Jourlal of Agricultural and Food Chemistry, 52(9) : 2485-2489.

- Mohammad, B.; Abolfazl ,A. T.; Mohammad, H. G.; Mohammad, A.; Shahram, E. M.; Mahnaz, K and Gholamreza, H.(2012). Neuroprotective 
properties of Melissa officinalis after hypoxic-ischemic injury both in vitro and in vivo. DARU Journal of Pharmaceutical Sciences.20(42),1:10.

-Moller, P. and Wallin, H. (1998). Adduct formation, mutagenesis and nucleotide excision repair of DNA damage produced by reactive oxygen species and lipid peroxidation product. Mutat. Res., 410 (3):271-290.

-Montgomery, H.A. and Dymock, J.F. (1961): Colorimetric determination of nitrite. Analyst., 86- 414.

-Nishikimi, M.; Appaji, N. and Yagi, K. (1972). The occurrence of superoxide anion in the reaction of reduced phenazine methosulfate and molecular oxygen. Biochem. Biophys. Res. Commun.,46(2):849-854.

-Omale J.; Okafor P.N. (2008). Coperative antioxidant capacity, membrane stabilization, polyphenol composition and cytotoxity of the leaf and stem of Cissus multistriata. African Journal of Biotechnology,. 7(17), : 3129-3133.

- Ordonez ,A.A.L.;Gomez, J.G.;Vattuone, M.A.;Isla,M.I.( 2006).Food Chem.97,452.

-Paglia, D.F. and Valentaine, W.N. (1979). Studies on glutathione and glutathione characterization of erythrocytes glutathione peroxidase. J.Lab.Clin.Med., 70(1):158-169.

- Parisa Jandaghi .;Mostafa, N.;Hamidreza ,A and Mahmoud, A.(2016). Lemon balm: A promising herbal therapy for patients with borderline hyperlipidemia - A randomized double-blind placebo-controlled clinical trial. Complementary Therapies in Medicine. 26: 136-140.

-Pereira, R.P.; Fachinetto, R.; de Souza, P. A.; Puntel, R.L and Santos da, S. G.N.(2009).Antioxidant effects of different extracts from Melissa officinalis, Matricaria recutita and Cymbopogon citratus. Neurochem Res, 34: 973-983.

- Pourmorad, B.; Hosseinimehr, S.J and Shanabi ,M. N. (2006). Antioxidant activity, phenol and flavonoid contents of some selected Iranian medicinal plants. African Journal of Biotechnology, 5(11), :1142-1145.

-Pyo ,Y.H.; Lee ,T.C.; Logendra, L and Rosen, R.T.( 2004).Antioxidant activity and phenolic compounds of Swiss chard (Beta vulgaris subspecies cycla) extracts. Food Chem, 85: 19-26.

-Reeves, P. G.; Nielsen, F. H. and Fahmy, G. C. (1993). AIN-93 purified diets for laboratory rodents: Final report of the American Institute of Nutrition ad hoc writing committee on the reformulation of the AIN-76A rodent diet. J. Nutr.; 123(11):1939-1951.

- Reitman, S. and Frankel, S. (1957). Determination of glutamate pyruvate transferase. Am. J. Clin. Path. 28:56. 
-Robeiro, M.A.; Bernardo-Gil, M.G and Esquivel, M.M. (2004). Mentha officinalis L. : study of antioxidant activity in supercritical residues. Jounal of Supercritical Fluids, 21(1): 51-60.

-Rosety ,M.; Rosety, R. M and Ordonez, F.J.(2005). Time course variations of antioxidant enzyme activities and histopathology of gilthead seabream gills exposed to malathion. Histol Histopathol:;20(4):1017-1020.

- Sanz,M.J.; Ferrandiz,M.L.; Cejudo,M.; Terencio,M.C.; Gil,B.; Bustos,G.; Ubeda,A.; Gunasegaran,R and Alcaraz ,M.J.(1994). Influence of a series of natural flavonoids on free radical generating systems and oxidative stress.Journal Xenobiotica.24,689-699.

-Schettler, G. and Nussel,E. (1975). Arb.Med.Soz.Med.Prav.Med.,10:25.

-Schulz, V.; Hansel, R and Tyler, V.( 2004). Rational Phytotherapy: a physician's guide to herbal medicine, $5^{\text {th }}$ Ed. New York, Springer Press. 63-68.

-Sepide Miraj.; Rafieian-Kopaei and Sara Kiani.(2017). Melissa officinalis L: A Review Study With an Antioxidant Prospective. Journal of EvidenceBased Complementary \& Alternative Medicine,22(3): 385-394.

-Shah, N.M.; Rushworth, S.A.; Murray, M.Y.; Bowles, K.M and MacEwan, D.J. (2013). Understanding the role of Nrf2-regulated mirnas in human malignancies. Oncotarget, 4, 1130-1142.

-Shelbaya, L.A.;El Mehairy, H. F. and El-Zainy Antioxidant, A.R.(2014). Activities of Marjoram (Origanum majoranum L.) added to frozen beef kofta and its therapeutic effect against kidney damage in rats. Wor. App. Sci. J., 31 (8): 1406-1414.

- Sief, M.M.; Khalil, F.A and Abou-Arab, A.A.(2015). Ameliorative role of 80elissa officinalis against hepatorenal toxicities of organophosphorus malathion in male rats. MOJ Toxicol.;1(3):103-109.

-Sinha, K. A. (1972). Colorimetric assay of catalase enzyme. Anal,Biochem., 47(2): 389-394.

- Steel, R. G. and Torri, J. H. (1980). Principal and Procedures of Statistical, Biometrical Approach. Pbl. Mc Grew Hill Book Company. $2^{\text {nd }}$ ed. New York, U.S.A.

-Vasques, E.R.; Cunha, J.E.; Coelho, A.M.; Sampietre, S.N.; Patzina, R.A.; Abdo, E.E.; Nader, H.B.; Tersariol, I.L.;Lima, M.A and Godoy, C.M.(2016). Trisulfate disaccharide decreases calcium overload and protects liver injury secondary to liver ischemia/reperfusion. PloS ONE, 11, e0149630.

-Wolfe K.;Wu,X and Liu,R.H.(2003).Antioxidant activity of apple peels.J.Agric.Food Chem.51,609. 
-Woodford, F.P. and Whitehead, T.P. (1998). Is measuring serum antioxidant capacity clinically useful? Ann. Clin. Biochem., 35:48-56.

-Xufeng Tao .; Xiance Sun .; Lina Xu .; Lianhong Yin .; Xu Han .; Yan Qi .; Youwei Xu .; Yanyan Zhao .; Changyuan Wang and Jinyong Peng .(2016). Total Flavonoids from Rosa laevigata Michx Fruit Ameliorates Hepatic Ischemia/Reperfusion Injury through Inhibition of Oxidative Stress and Inflammation in Rats.Journal Nutrients, 8, 418.

-Yoshikava, M.; Xu ,F.; Morikava, T.; Ninomya, K and Matsuda, H. (2003). Anaststins $A$ and $B$, new skeletal flavonoids with hepatoprotective activities from the desert plant Anastatica hierochuntica. Bioorg Med chem Lett, 13:1045-1049.

-Zeraatpishe, A.; Oryan,S.;. Bagheri, M.H.; Pilevarian, A .A .; Malekirad, A.A.; Baeeri,M and Abdollahi, M.(2011). Effects of Melissa officinalis L. on oxidative status and DNA damage in subjects exposed to long-term low-dose ionizing radiation. Toxicol. Ind. Health., 7: 205-212.

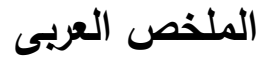

تأثير الخبز المدعم بالمليسيا ضد الأجهاد التأكسدى المحدث فى الجرذان

تعرف نبات المليسيا أيضًا باسم بلسم النحل ، بلسم الليمون ، بلسم العسل ، وهو عشب معمر . وهو

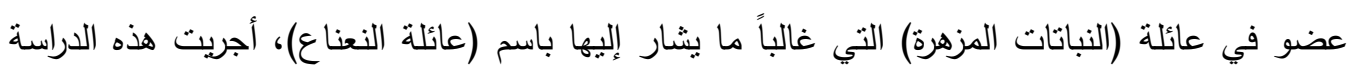

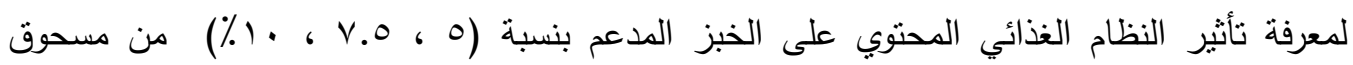

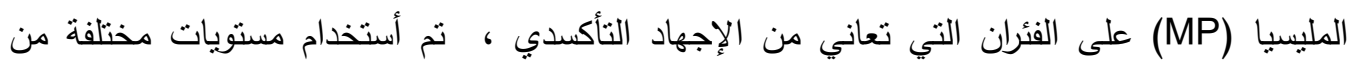

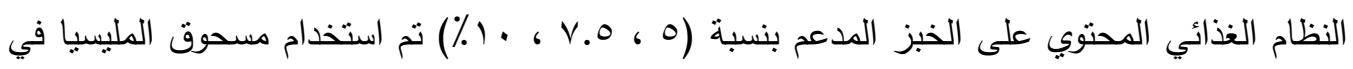
تحضير الخبز المختبرة التي خضعت للتقييم الحسي ، وكان أفضل مستوى للخبز الددعم بعد التقييم

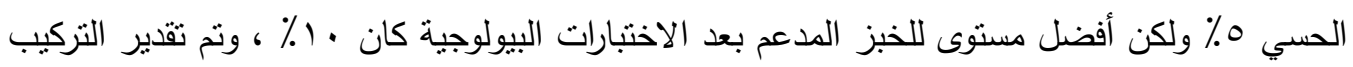

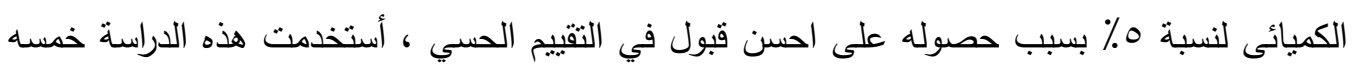

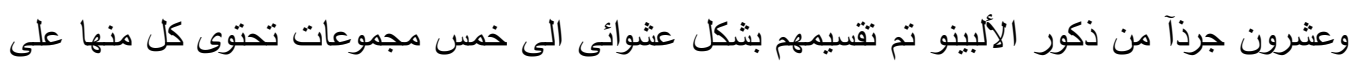

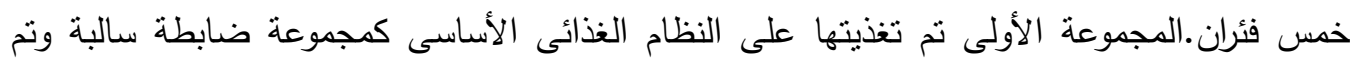

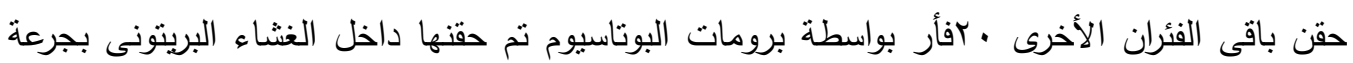


واحدة(ب املجم / كجم من وزن الجسم) لأحداث الإجهاد التأكسي ، بعد ذلك تم تقسيم المجموعات

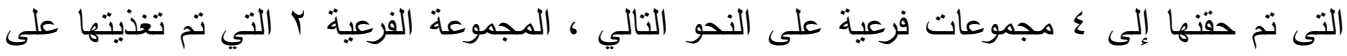
النظام الغذائي الأساسي تحتوي على خبز غير مدعم كمجموعة كنترول موجبة ، المجموعات الفرعية ب

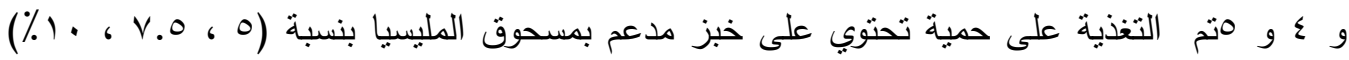

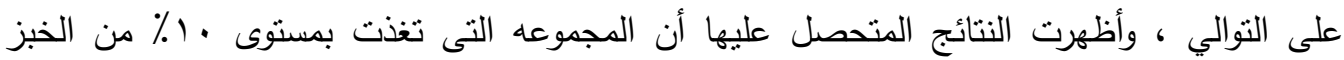

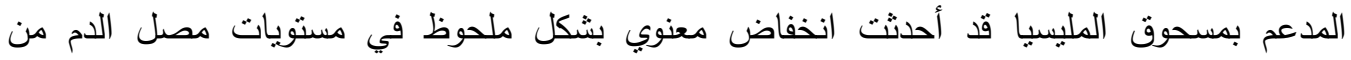
الكوليسترول الكلي ، الدهون الثلاثية ، الليبوبروتينات منخفضة الكثافة LDL-C ، الليبوبروتينات

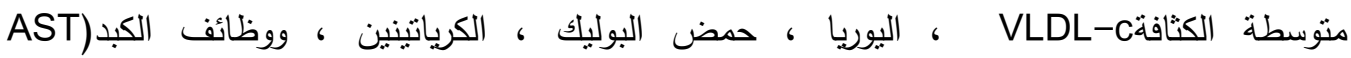
HDL- وزيادة ملحوظة في مستويات المصل من الليبوبروتينات عالية الكثافة ،

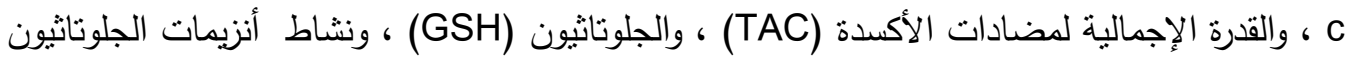

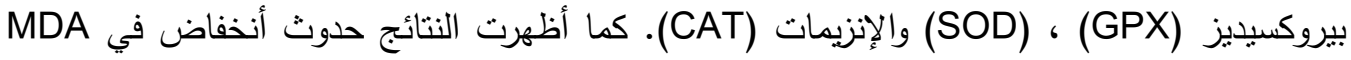

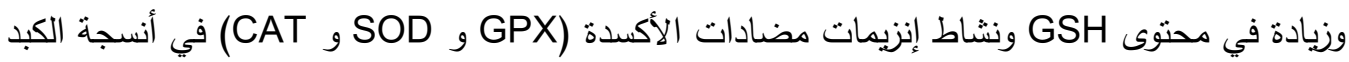

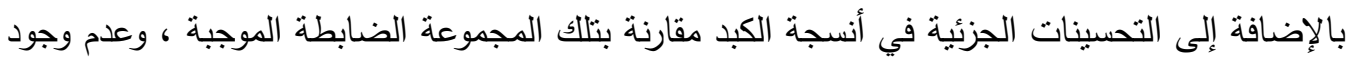
فروق معنوية تذكر بالنسبة للطعام المأخوذ والنسبة المئوية للزيادة فى وزن الجسم ومدى الاستفادة من

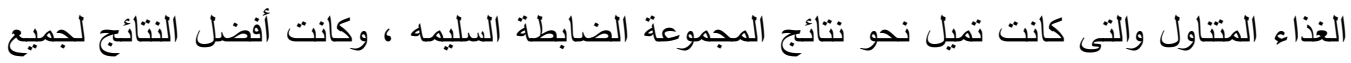
المؤشرات البيوكيميائية والهسنوباثولوجية لانسجة الكبد والتى كانت قريبة من النتائج الطبيعية كانت للمجموعة التى تغذت على الخبز الددعم ب • 1\% من مسحوق المليسيا فى النهاية تثبير النتائج الحالية

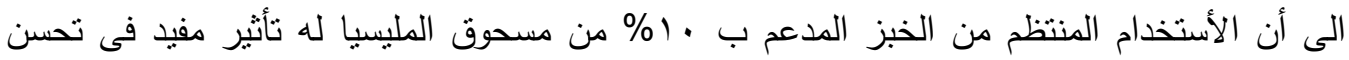
وظائف الكبد والكلى ويعد عامل وقائى ضد الأجهاد التأكسى المحدث ببرومات البوتاسيوم فى الفئران.

الكلمات المفتاحية: أنزيمات مضادات الأكسدة ، وظائف الكبد ، وظائف الكلى ، دهون الدم، مليسيا ، الأجهاد التأكسدى ، الفئران. 